\title{
The English Expedition to Sokotra
}

\section{Author(s): H. O. Forbes}

Source: The Geographical Journal, Vol. 13, No. 6 (Jun., 1899), pp. 633-637

Published by: geographicalj

Stable URL: http://www.jstor.org/stable/1774416

Accessed: 26-06-2016 20:20 UTC

\section{Your use of the JSTOR archive indicates your acceptance of the Terms \& Conditions of Use, available at}

http://about.jstor.org/terms

JSTOR is a not-for-profit service that helps scholars, researchers, and students discover, use, and build upon a wide range of content in a trusted digital archive. We use information technology and tools to increase productivity and facilitate new forms of scholarship. For more information about JSTOR, please contact support@jstor.org.

The Royal Geographical Society (with the Institute of British Geographers), Wiley are collaborating with JSTOR to digitize, preserve and extend access to The Geographical Journal 
Chapter XI. describes the harmonic analysis of tides by substitution of imaginary satellites for the sun and moon; Chapter XII. the actual methods of reducing tidal observations and determining the fifteen or twenty pairs of constants required to form a complete record of the behaviour of the sea at a particular place; and Chapter XIII. the use of Kelvin's harmonic analyzer in constructing tide-predicting tables from known constants.

After a comparison of tides predicted and observed, chiefly at Portsmouth, which gives an estimate of the degree of accuracy attainable in tide-predicting, Prof. Darwin leaves the subject of sea-tides, and the remainder of the book treats of tidal problems of a more general order. Of the chapters on the rigidity of the Earth, on tidal friction, on figures of equilibrium in a rotating mass of liquid, on the nebular theory, and on Saturn's rings, it would be difficult to say which is the finest example of popular treatment of the best sort. We commend them to the study of geomorphologists.

Not the least merit of this admirable book is the list of references to authorities at the end of each chapter. The part most susceptible of improvement is perhaps the illustrations; we should like to see more of them in the next edition; and a few, notably Fig. 23, might be made somewhat clearer or explained more fully.

\section{THE ENGLISH EXPEDITION TO SOKOTRA.}

By Dr. H. O. FORBES.

This expedition was undertaken conjointly by the British and Liverpool Museums, aided by the Royal Society of London, the Royal Geographical Society, and the British Association, with the zoological investigation of the island as its main object. The members were the Director of the Liverpool Museums (Dr. H. O. Forbes) and Mr. W. R. Ogilvie-Grant, of the British Museum. An experienced taxidermist from the former institution, six Somali servants, and a native officer, with one sowar from the Aden troop, completed the party. Dr. Forbes has sent us the following account of the expedition :-

We left England on October 28, 1898, on board the British India steamer Manora. Through arrangements kindly permitted by the directors of the company, and made by Captain Henderson, a collection of the plankton all the way from the English Channel to Aden was continuously kept up, by attaching grit-gauze nets to one of the pumps constantly in action when the steamer was under way.

We arrived in Aden on November 18, but, on being received by the Political Resident, Brigadier-General Creagh, v.c., we were deeply disappointed to learn that political difficulties, which had arisen between the Indian Government and the Sultan of Sokotra, would probably 
prevent our proceeding to our destination. The general displayed the greatest sympathy with us in our disappointment, and without delay communicated on the subject with the Indian authorities. Meanwhile we were assisted in the very kindest manner, both by the Resident and by Captain Jacob, the First Political Assistant, to tide over the detention unavoidable to the negotiations, as profitably to the objects of our journey as possible. The general lent us the Government bungalow at Sheik Othman, some 12 miles from Aden; and recommended us to the Sultan of Lakej, from whom we received a cordial invitation to visit his territory, and, should it be impossible to proceed to Sokotra, to make as prolonged a stay in it as we desired. On November 27, however, we were recalled from Lakej by the arrival of a telegram from the Indian Government, authorizing our visit to Sokotra. Hurrying back, therefore, to Aden, we engaged the necessary servants and embarked on December 1, on board the Elphinstone, a steamer of the Royal Indian Marine, which the Government of India had generously placed at our disposal to convey us to and from the island.

Just before our departure, we had the satisfaction of making the acquaintance of the members of the Austrian Expedition to Arabia, which was chiefly in quest of Himyaritic inscriptions-Count Landberg, Dr. H. Müller, Dr. Kossmat, and Prof. Simony. This expedition, later on, also visited Sokotra, and we had the pleasure of receiving several of the party at our camp at Adho Dimellus.

The outward voyage was broken at Abd-el-Kuri, an islet lying some 200 miles east of Guardafui, which had never before been scientifically investigated. The Elphinstone anchored at Bander Saleh, on the south coast, and four days were spent in making zoological, botanical, and geological collections, among which several animals and plants have proved new to science. The geological structure of the island is very similar to that of Sokotra. It has suffered great denudation, however, for the limestone, which is of both Cretaceous and Tertiary age, has disappeared everywhere, except on one or two summits. Volcanic rocks abound, and from the high peak-1750 feet in height-overlooking our anchorage they resembled a number of papillæ rising from a desert of sand. The island has but few inhabitants, who are very poor and miserably housed. Some of them are fishers and divers for pearl-shell. Numerous chelonian carapaces strewn about near their huts indicated that the hawk's-bill turtle was a common frequenter of their coasts. The most notable feature of the vegetation was the absence of those characteristic plants of Sokotra, the dragon's blood (Dracæna cinnabari, and other species of the genus), the myrrh and the frankincense trees, though Abd-el-Kuri lies nearer to the African coast than the main island.

On December 6 the Elphinstone continued on her voyage to Sokotra, when, after landing us near Hadibu, she returned to Aden. Our first camp was placed on the banks of the Hanefu, in the beautiful plain south 
of the capital, where collections were commenced, a base for the survey measured, and astronomical observations taken. The Sultan was at first not too favourably inclined to us, and the people avaricious and averse to giving us information about the roads and passes of the country, which caused us not a little loss of time. On the 18th of the month we moved our camp to Dahamis, lying under the peak of Aduna, at 740 feet, in a valley looking north-east. Here, on the fourteenth day after our landing, fever of a malignant and very intractable type appeared among us. It was rarely preceded by an ague stage, but was marked by lengthy periods of unbroken high temperature, often reaching $106^{\circ}$ Fahr., and by irreducible sickness. Our Somali, Arab, and Indian companions suffered equally with ourselves.

From Dahamis we moved first to Kamahanu, a hill in the Garieh plain, and then to Jena-agahan, a still higher altitude, in the hope of getting rid of the fever. Jena-agahan is a flat eminence on one of the spurs of the Haghier range. The name Haghier, by the way, signifies "white rocks," a designation applied to them, no doubt, from the white lichen which entirely covers the bare granite summits, which present a striking contrast to the red of the lower slopes, on which the plant does not thrive. On the plain below our camp the wild ass, which most travellers to the island have mentioned, roamed in considerable herds. Larger than the domestic animal, it is a strong, square-built beast, with a pure white muzzle, and white margins to its not over-long ears; above, it is slaty-grey, with a black stripe across its shoulders, and another down its back to the tip of the tail. Its under-surface is white, with the exception of two black anklets. It closely resembles the onagar, and it may perhaps prove to be a new indigenous species, although by some naturalists it is considered to be but the common ass escaped from captivity. In many parts of the plain occur long lines of large stones laid out on the ground amid the scrub, placed there, as the natives tell, by the "Kafirs" "long ago." They look like boundary fences, only they are not long enough, and the directions they pursue are too irregular for such a purpose. In this district of the Haghier mountains we found, high up on the summits, the dragon's-blood tree in great abundance, myrrh and frankincense trees also, and candelabra-like euphorbiasall specially characteristic of the Sokotra flora. In the sunny ravines near our camp insects were abundant, especially a fine new species of Charaxes, recently described by Mr. Grant under the name of C. velox in the Bulletin of the Liverpool Museums, vol. ii. May, 1899, where in pages 1 to 13 will be found the descriptions of the more conspicuous novelties in the groups so far examined, obtained during the expedition.

On January 15, once more shifting our quarters, and crossing the Garieh plain eastward, we camped on the plateau of Hombil (1700 feet in height), in a curious parabolic amphitheatre a couple of miles wide, 
whose walls were of limestone nearly 1000 feet high, and its floor of archæan rocks from which the limestone has apparently been removed by some remarkable process of denudation. Part of this limestone is, from various indications, probably contemporaneous with that out of which the peaks of Sinai protrude. This plateau is the nearest approach the limestone formation makes to the spurs of the Haghier mountains on their eastern face; the whole width of the Garieh plain separates the one from the other. All round the bases of the southern and western spurs of this orographic block the limestone overlies the granite.

Our sojourn at Homhil proved a very profitable one. The health of the camp improved amazingly, notwithstanding that fever was prevalent among the Sokoteri, and occasionally appeared among our own natives, and mosquitoes showed no decrease in numbers. The vegetation on the limestone flanks and summits of Hamaderu and Matagoti was rich and abundant. Dorstenias, Adeniums, Trichodesmas (of two varieties, deep blue and pure white), Exacums (the most beautiful and sweetly scented of gentians), with a luxuriant shrubbery of boxwood (Buxus hildebrandti), afforded interest and pleasure of no ordinary kind.

Leaving Homhil, we turned westwards and ascended to Adho Dimellus, at an elevation of about 4000 feet, in the centre of the Haghier massif, and just under Ferahe, its culminating peak. Our camp was pitched nearly on the water-parting of three deep cañon-like valleys, stretching one to the north and two to the south. The granite walls of the latter were in many places sheer precipices of great height, and the valleys between them look like gigantic fauit-blocks which have dropped bodily down. This was one of the most salubrious, picturesque, and exhilarating regions imaginable, and it is difficult to express the supreme enjoyment of our stay there. The ground was densely clad with Euryops and Hypericums, of which one splendid species, a large bushy shrub, was everywhere starred over with blossoms exceeding in size and depth of golden yellow those of our own Large-flowering St. John's-wort. The open spaces between the boulders-which in Sokotra everywhere cover the surface-and the bushes were carpeted with Cystistemons and deepblue Trichodesmas; while against the bare rock-faces, and sharing the almost soil-less clefts of the granite with the Exacums, the Sokotran Begonia spread its orbicular leaves and thrust up its fine heads of rich pink flowers. On the precipitous slopes grew, in greater abundance than we observed elsewhere, both Boswellias and Balsamodendrons (the myrrh and frankincense trees); and the very highest pinnacles were held by the largest of the dragon's-blood trees. Indeed, it is mainly on the highest regions of the range that the more peculiar flora of the island is developed.

Near our camp also were extensive meadow-like areas-the pasturegrounds of large herds of the shapely and inquisitive little cattle of the island-over which are dotted the ruins of square mortar-built houses, 
of ancient circular cyclopean dwellings resembling somewhat those to be seen in parts of Mashonaland, long stone dykes, and large antique corn-mortars, erected and set up by people of whom the present inhabitants have no knowledge.

Owing to our detention in Aden, and thu time subsequently lost through sickness, it was impossible for us to extend our investigations, as we had intended, to the western portion of the island. On February 18 the expedition had regretfully to pack up and return to Hadibu, to await the return of the Elphinstone to carry us back to Aden. On the 21st we embarked, and, after a couple of days spent in revisiting Abdel-Kuri, reached Aden on the 26th.

As the fauna of Sokotra appears, in our experience, to be pretty uniformly distributed from the coast to the mountain-tops, we have probably, therefore, obtained representatives of most of the species on the island. On the other hand, much of the flora of the higher altitudes is not to be found in the lowlands. Botany was not a special object of investigation with us, as, after the very thorough examination of the island by Prof. Balfour, we could not expect to add many new plants; still, a few undescribed species have been obtained. In this department our time was chiefly devoted to collecting seeds and living specimens, of which a large number of great horticultural and scientific interest have been successfully transferred to this country.

Our contributions to the anthropology of Sokotra are, unfortunately, not very extensive. The shyness and fanaticism of the people, together with the difficulties of the language, even with the services of an excellent interpreter at one's command, are almost insuperable hindrances to obtaining accurate information in this department during a short visit.

The portion of the island visited by us has been surveyed with some care, and a considerable number of astronomical observations have been obtained. The map published by Wellsted we found to be extremely inaccurate everywhere except as regards the coast-line.

When the members of the Austrian expedition visited us at Adbo Dimellus in February, they very generously proposed to wait for the publication of our biological collections before issuing the results of theirs, so as to prevent the duplication of types. In order, also, that the survey should be as complete as possible, it was agreed that the observations of both expeditions should be incorporated in one, probably a combined topographical and geological, map, for Prof. Kosmat's geological investigations are very extensive; they will undoubtedly prove of the highest value.

A fully illustrated account of the biological results of our expedition will shortly appear as a special Bulletin of the Liverpool Museums. 